\title{
Identification of metal-tolerant organisms isolated from the Plankenburg River, Western Cape, South Africa
}

\author{
VA Jackson ${ }^{1,3}$, AN Paulse ${ }^{1,2}$, JP Odendaal' ${ }^{2}$, Khan'and W Khan ${ }^{3 *}$ \\ ${ }^{1}$ Department of Biomedical Sciences, Faculty of Health and Wellness Sciences, Cape Peninsula University of Technology, \\ Bellville 7535, South Africa \\ ${ }^{2}$ Department of Environmental and Occupational Studies, Faculty of Applied Sciences, Cape Peninsula University of Technology, \\ Cape Town 8000, South Africa \\ ${ }^{3}$ Department of Agricultural and Food Sciences, Faculty of Applied Science, Cape Peninsula University of Technology, \\ Cape Town 8000, South Africa
}

\begin{abstract}
The ability of biofilms to resist pollutants makes them advantageous for use in bioremediation. The objective of this investigation was to isolate metal-tolerant micro-organisms from a site along the Plankenburg River. Microbial biofilms cultivated in multi-channelled flow cells were exposed to varying concentrations of aluminium ( $\mathrm{Al})$, iron ( $\mathrm{Fe})$, copper $(\mathrm{Cu})$, manganese $(\mathrm{Mn})$, nickel $(\mathrm{Ni})$ and zinc $(\mathrm{Zn})$, stained with the BacLight ${ }^{\mathrm{TM}}$ viability probe, visualised using epifluorescence microscopy and analysed using ScionImage. Exposure to the highest Al, Fe, $\mathrm{Cu}$ and $\mathrm{Mn}$ concentrations increased the percentages of dead cells. A difference in live and dead cells after exposure to varying $\mathrm{Zn}$ and $\mathrm{Ni}$ concentrations was not evident. When exposed to the lowest concentrations, no notable difference could be detected in comparison with the untreated control. Possible metal-tolerant micro-organisms were identified from the exposed flow cells using polymerase chain reaction (PCR) and deoxyribonucleic acid (DNA) sequencing, followed by ClustalX alignment and phylogenetic analysis. Phylogenetic analysis identified a variety of organisms, including Bacillus sp., Pseudomonas sp., Delftia tsuruhatensis strain A90, Kocuria kristinae strain 6J-5b, Comamonas testosteroni WDL7, Stenotrophomonas maltophilia strain 776, Staphylococcus sp. MOLA:313, Micrococcus sp. TPR14, Sphingomonas sp. 8b-1 and Microbacterium sp. PAO-12. Two major clusters could be distinguished based on their Gram-reactions.
\end{abstract}

Keywords: BacLight ${ }^{\mathrm{TM}}$ viability probe, biofilms, phylogenetic analysis, river water, ScionImage

\section{Introduction}

Population growth and urbanisation results in increased water resource utilisation. Continued deposition of point- and nonpoint source pollutants, including those originating from industrial effluents, agricultural runoff, leaking sewers, on-site sanitation at informal housing and waste irrigation (DEAT, 1996), amongst others, adversely affects the surrounding environment. Metal contamination in the environment can also be attributed to the natural occurrence of metals in soil, atmospheric deposits and the corrosion of building materials (Maanan et al., 2004). The metals most commonly associated with most river water systems are lead $(\mathrm{Pb})$, copper $(\mathrm{Cu})$, iron $(\mathrm{Fe})$, cadmium $(\mathrm{Cd})$, aluminium $(\mathrm{Al})$, mercury $(\mathrm{Hg})$, arsenic (As) and manganese (Mn) (Wright and Welbourne, 2002). Zinc (Zn), nickel (Ni), As, Hg, cobalt (Co) and Mn concentrations were studied in water and fish samples isolated from the Aba River, Nigeria, into which waste from various industries is discharged. Atomic absorption spectrometry (AAS) analysis revealed elevated concentrations of $\mathrm{Zn}, \mathrm{Mn}$ and As in fresh fish and elevated $\mathrm{Ni}$ and $\mathrm{Hg}$ concentrations in frozen fish found in a nearby market (Allinnor, 2005).

In water and the environment, micro-organisms exist mostly as biofilm communities attached to surfaces; microbial biofilms exhibit high affinities for contaminants due to the ability of the exopolymers to bind and sequester antimicrobial

\footnotetext{
* To whom all correspondence should be addressed.

III +27 21 460-9095; fax: +27 21 460-3193; e-mail: wesaalkhan5@gmail.com

Received 28 January 2011; accepted in revised form 14 December 2011.
}

agents from the surrounding environment (Teitzel and Parsek, 2003). Biofilms have been shown by Roane and Pepper (2000) to be one of the most effective treatments for the removal of metals from metal-contaminated water.

Flow cell systems have been used to cultivate microbial biofilms in vivo (Caldwell et al., 2002). They are multichannelled to allow for experimental replication and simplified handling. Teitzel and Parsek (2003) used a flow cell system to visualise the behaviour of biofilm-bound micro-organisms in response to $\mathrm{Cu}$ and $\mathrm{Zn}$. Confocal laser scanning microscopy (CLSM) analysis revealed that the majority of cells in the outer layers were dead, in comparison to the untreated control, where the majority of cells were alive.

Microbial composition can be determined genetically, through the amplification of the $16 \mathrm{~S}$ or $23 \mathrm{~S}$ rRNA region of the genomic DNA, using specific primers (Amann, 1995). The diversity of tolerant micro-organisms depends on nucleotide sequence variations (Martin, 2002), ranging from $20 \%$ to $80 \%$ $\mathrm{G}+\mathrm{C}$ (Ochman et al., 2005) among individual species sharing common ancestry. This genetic variation can then be visualised with phylogenetic trees (Martin, 2002).

Chien et al. (2007) studied the microbial diversity in soil contaminated with effluent from a chemical industrial factory, using 16S rDNA. The organisms isolated were Polyangium spp., Sphingomonas spp., Variovorax spp., Hafina spp., Clostridia, Acidobacteria, the enterics and some uncultured strains. Acinetobacter, Enterobacter and Stenotrophomonas spp. also exhibited the ability to tolerate high concentrations of Cd.

The objective of this investigation was to isolate metaltolerant micro-organisms from a metal-contaminated site along the Plankenburg River. The micro-organisms were cultured 


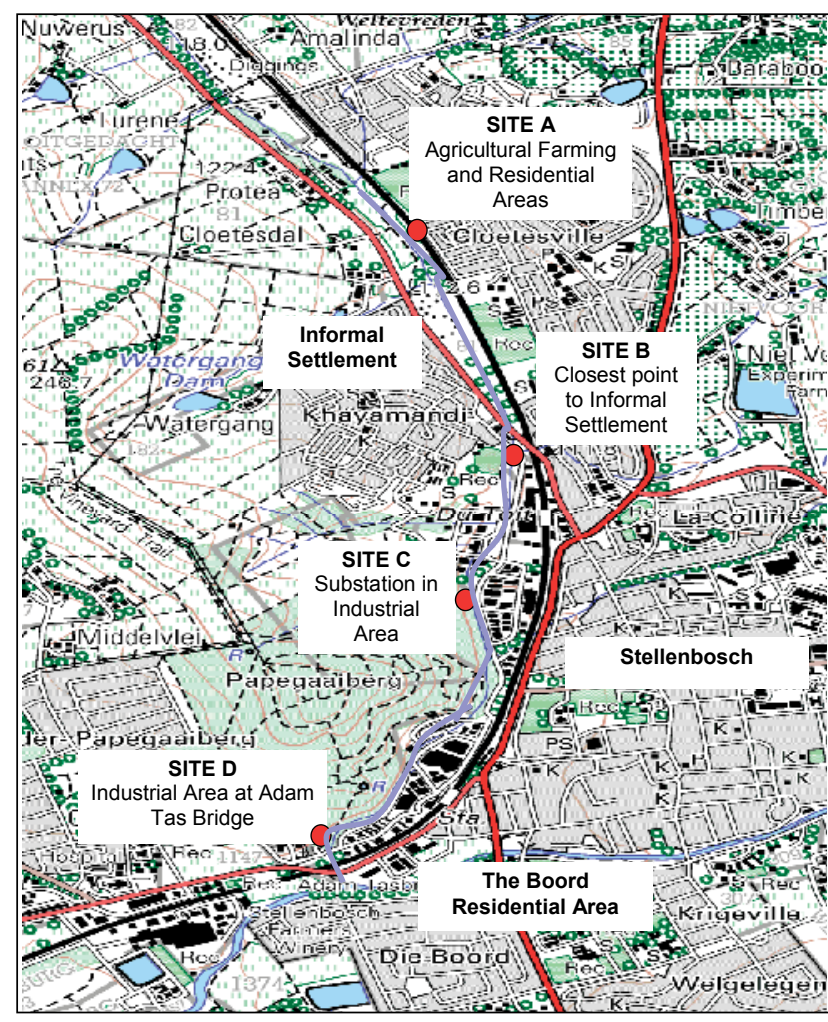

Figure 1

Map of the Plankenburg River indicating the different sampling points: Site A - Agricultural farming and residential areas; Site $B$ - closest point to informal settlement; Site $C$ - Substation in industrial area and Site D - Industrial area at Adam Tas Bridge

and isolated in flow cell systems after exposure to varying metal concentrations, identified using the polymerase chain reaction $(\mathrm{PCR})$ technique and analysed phylogenetically.

\section{Materials and methods}

\section{Site description}

A previous study identified 4 sampling sites along the Plankenburg River (Fig. 1) (Jackson et al., 2009). These sites included Site A (Agricultural farming and residential areas) and Site B (Industrial area at Adam Tas Bridge). Results from this study showed that the highest concentrations of metals were recorded at Site C (Substation in the industrial area), which is why this particular site was selected to investigate the efficiency of the bioreactor systems to reduce metal concentrations in the river water. Ten litres of river water was collected from Site C (Fig. 1) in a $10 \ell$ plastic container and transported at $4^{\circ} \mathrm{C}$.

\section{Metal concentrations in river water}

To determine the concentrations of $\mathrm{Al}, \mathrm{Cu}, \mathrm{Fe}, \mathrm{Mn}, \mathrm{Ni}$ and $\mathrm{Zn}$ in water, $5 \mathrm{~m} \ell$ samples were digested with $10 \mathrm{~m} \ell 55 \%$ nitric acid at $40^{\circ} \mathrm{C}$ for $60 \mathrm{~min}$ and then at $120^{\circ} \mathrm{C}$ for $180 \mathrm{~min}$, using a Grant dry-block heater. A blank (control) of $10 \mathrm{~m} \ell 55 \%$ nitric acid was analysed along with the collected samples to check for possible contamination. The samples were cooled to room temperature, filtered with Whatman No. 6 filter paper into $20 \mathrm{~m} \ell$ volumetric flasks, made up to a volume of $20 \mathrm{~m} \ell$ with distilled water and subsequently filtered for a second time using $0.45 \mathrm{~mm}$ cellulose nitrate ultrafiltration membrane filters (Whatman) (Odendaal and Reinecke, 1999). Metal concentrations were determined using inductively coupled plasma atomic emission spectrometry (ICP-AES) analysis according to the procedure outlined in Saleh et al. (2000).

\section{Flow cell experiment}

Six multi-channelled ( 8 channels) flow cells were constructed from Perspex, a glass coverslip and silicone tubing. The flow channels were $5 \mathrm{~mm}$ wide, $30 \mathrm{~mm}$ long, $3 \mathrm{~mm}$ deep and a distance of $4 \mathrm{~mm}$ from the next channel. The glass coverslip (50 mm x $75 \mathrm{~mm}$ ) was secured to the top of the flow cell with marine silicone glue and provided an attachment surface for the microbial growth. Silicone tubing $(1.6 \mathrm{~mm})$ was used for the flow through the respective channels from the reservoirs (influent - collected river water) to the outlet (effluent). After construction, the flow cells were sterilised with a solution of sodium hypochlorite and flushed with distilled water (Fig. 2). The collected river water was pumped through the flow cell systems, using a Watson Marlow peristaltic pump (205S) (Watson Marlow Limited, Cornwall, England), to ensure a constant flow rate at $2 \mathrm{r} \cdot \mathrm{min}^{-1}$. After a 3-week period, which allowed for maximum biofilm
Figure 2

Multi-channel flow cell system to isolate metaltolerant organisms. $A$ - untreated control (Channels 1 and 2), $B$ - highest concentration (Channels 3 and 4), C-second lowest concentration (Channels 5 and 6) and $D$ - lowest concentration (Channels 7 and 8)

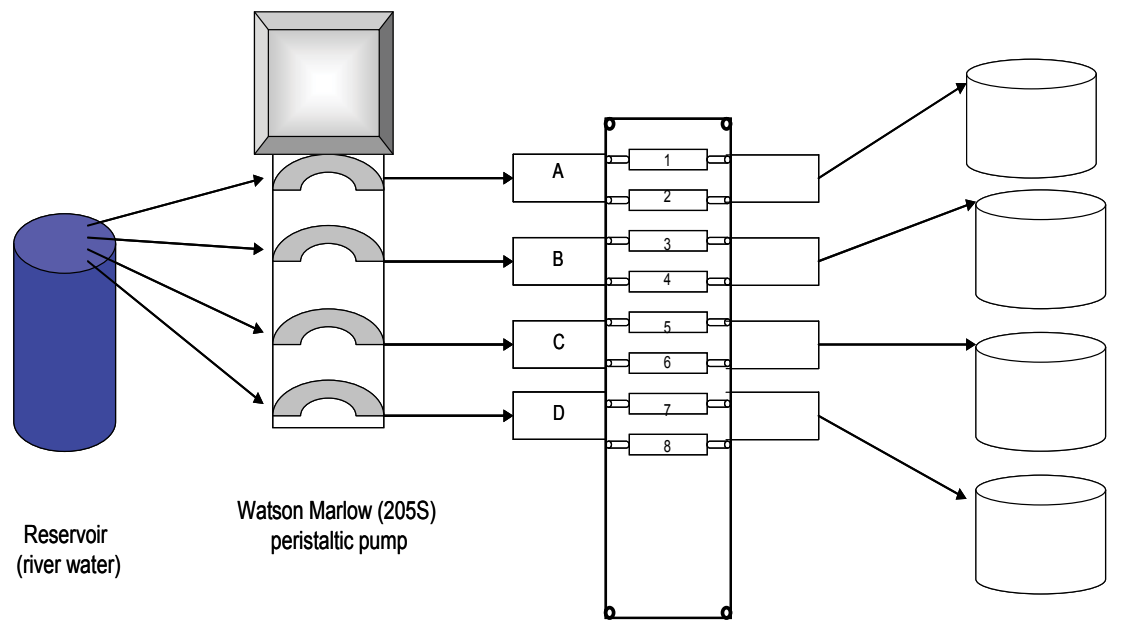

Multi-channelled flow cell, with coverslip attached
Outlet/Effluent 


\begin{tabular}{|l|l|c|c|c|}
\hline \multicolumn{5}{|c|}{$\begin{array}{c}\text { Table 1 } \\
\text { Representation of the different concentrations of metals (Al, Cu, Fe, Mn, Ni and Zn) } \\
\text { to which the six respective flow cells channels were exposed }\end{array}$} \\
\hline Metals & $\begin{array}{c}\text { Flow cell channels } \\
\text { one and two }\end{array}$ & $\begin{array}{c}\text { Flow cell channels } \\
\text { three and four }\end{array}$ & $\begin{array}{c}\text { Flow cell channels } \\
\text { five and six }\end{array}$ & $\begin{array}{c}\text { Flow cell channels } \\
\text { seven and eight }\end{array}$ \\
\hline $\mathrm{Al}$ & Untreated control & $900 \mathrm{mg} \cdot \ell^{-1}$ & $500 \mathrm{mg} \cdot \ell^{-1}$ & $10 \mathrm{mg} \cdot \ell^{-1}$ \\
\hline $\mathrm{Cu}$ & Untreated control & $10 \mathrm{mg} \cdot \ell^{-1}$ & $2.5 \mathrm{mg} \cdot \ell^{-1}$ & $0.5 \mathrm{mg} \cdot \ell^{-1}$ \\
\hline $\mathrm{Fe}$ & Untreated control & $1000 \mathrm{mg} \cdot \ell^{-1}$ & $500 \mathrm{mg} \cdot \ell^{-1}$ & $10 \mathrm{mg} \cdot \ell^{-1}$ \\
\hline $\mathrm{Mn}$ & Untreated control & $80 \mathrm{mg} \cdot \ell^{-1}$ & $15 \mathrm{mg} \cdot \ell^{-1}$ & $1.5 \mathrm{mg} \cdot \ell^{-1}$ \\
\hline $\mathrm{Ni}$ & Untreated control & $20 \mathrm{mg} \cdot \ell^{-1}$ & $1 \mathrm{mg} \cdot \ell^{-1}$ & $0.5 \mathrm{mg} \cdot \ell^{-1}$ \\
\hline $\mathrm{Zn}$ & Untreated control & $40 \mathrm{mg} \cdot \ell^{-1}$ & $1 \mathrm{mg} \cdot \ell^{-1}$ & $0.5 \mathrm{mg} \cdot \ell^{-1}$ \\
\hline
\end{tabular}

growth, the channels were exposed to varying metal concentrations. Each flow cell was exposed to different concentrations of Al, Fe, $\mathrm{Cu}, \mathrm{Mn}, \mathrm{Ni}$ and $\mathrm{Zn}$ (Table 1), based on concentrations recorded during a previous study (Jackson et al., 2009). The first 2 channels of each flow cell were not exposed to any metals and served as the controls. Each flow cell channel was exposed to the respective metal concentrations for $6 \mathrm{~h}$, while the peristaltic pump was switched off and the tubing was clamped.

\section{Exposure to the Baclight ${ }^{\mathrm{TM}}$ viability probe}

After the 6-h metal exposure period, one of each channel spiked with the respective metal concentrations, as well as one of the unexposed control channels, was stained with the multifluor LIVE/DEAD Baclight ${ }^{\mathrm{TM}}$ fluorescent viability probe (invitrogen - Molecular Probes ${ }^{\mathrm{TM}}$, Oregon, USA). The stain was prepared by mixing $4 \mu \mathrm{g} \cdot \ell^{-1}$ of the green fluorescing probe (SYTO 9) with $4 \mu \mathrm{g} \cdot \ell^{-1}$ of the red fluorescing probe (propidium iodide) and $1 \mathrm{~m} \ell$ of distilled water. The probe was allowed to attach to the cell surfaces of the biofilm organisms for a period of 20 min. After the attachment period, the pump was switched on to remove any excess dye. The channels not exposed to the probe were flushed by turning the pump up to its maximum flow rate of $90 \mathrm{r} \cdot \mathrm{min}^{-1}$ in order to dislodge the attached biofilm growth. This microbial suspension was collected into individual $50 \mathrm{~m} \ell$ Schott bottles.

\section{Microscopy and image analysis}

Epifluorescence microscopy was used in conjunction with the LIVE/DEAD BacLight ${ }^{\mathrm{TM}}$ probe (invitrogen - Molecular Probes $^{\mathrm{TM}}$, Oregon, USA) in order to provide total cell counts, using images based on the relative abundance of microorganisms (Boulos et al., 1999). The images were visualised and captured using the Zeiss Axiovert 200 motorised fluorescence microscope, which contains the Dapi, Alexa, Cy3, GFP and Cy5 laser lines. It is also equipped with a monochrome Zeiss Axiocam HR digital camera. The 100X, 1.4 NA oil immersion objective was used to visualise the biofilm, along with an argon laser exciting the fluorophores. Ten randomlycaptured images along the surfaces of the attached coverslip were obtained from each of the exposed channels using the Axiovision 4.6 Software Programme (Zeiss imaging systems), which was further used for viewing and simple image processing. Ten images were randomly captured along the surfaces of the coverslips and the percentage area covered by living and non-living biomass was determined using ScionImage Analysis (Scioncorp.com). These techniques were performed in duplicate and the results obtained were the averages of the replicates.

\section{DNA extraction and agarose gel electrophoresis}

The flushed material, obtained from the unstained flow cell channels for each respective metal, was spread-plated onto nutrient agar plates and incubated at $37^{\circ} \mathrm{C}$ for 2 days. Single colonies were then selected in order to isolate pure cultures and DNA was extracted using the High Pure PCR Template Preparation Kit, as per the manufacturer's instructions (Roche Diagnostics GmbH, Mannheim, Germany). Ten microlitres of the extracted DNA samples were electrophoretically analysed on a $0.8 \%$ molecular grade agarose gel containing $12 \mu \ell$ of $0.5 \mu \mathrm{g} / \mathrm{m} \ell$ ethidiumbromide $(\mathrm{EtBr})$, using $1 \mathrm{x}$ Tris-acetate- ethylenediamine tetraacetic acid (TAE) electrophoresis buffer at $90 \mathrm{~V}$ for $1 \mathrm{~h}$.

\section{Polymerase chain reaction (PCR)}

Amplification of target DNA by PCR was performed in a total reaction volume of $50 \mu \ell$ containing $10 \mathrm{mM}$ dNTP Mix $(1 \mu \ell), 25 \mathrm{mM} \mathrm{MgCl}_{2}(3 \mu \ell), 10 \mathrm{X} \mathrm{Taq}$ Buffer with $\left(\mathrm{NH}_{4}\right)_{2} \mathrm{SO}_{4}(5 \mu \ell), 10 \mu \mathrm{M}$ forward (fDD2 CCGGATCCGTCGACAGAGTTTGATCITGGCTCAG) $(5 \mu \ell), 10 \mu \mathrm{M}$ reverse (rPP2 - CCAAGCTTCTAGACGGITACCTTGTTACGACTT) $(5 \mu \ell)$ (Rawlings, 1995), Taq DNA polymerase $(1 \mu \ell)\left(5 \mu \mathrm{g} \cdot 5 \mu \ell^{-1}\right)$ (Fermentas Life Sciences, EU), $1 \mu \ell$ of a concentrated DNA sample and $29 \mu \ell$ sterile distilled water. The amplification process included an initial denaturation step of $94^{\circ} \mathrm{C}$ for $2 \mathrm{~min}$, followed by 30 cycles of amplification $\left(1 \mathrm{~min}\right.$ at $94^{\circ} \mathrm{C}, 1 \mathrm{~min}$ at $57^{\circ} \mathrm{C}$ and $2 \mathrm{~min}$ at $72^{\circ} \mathrm{C}$ ). This was followed by a final extension step of $72^{\circ} \mathrm{C}$ for $10 \mathrm{~min}$. Ten microlitres of the subsequent PCR amplicons were then electrophoretically analysed on a $0.8 \%$ molecular grade agarose gel containing $12 \mu \ell$ of $0.5 \mu \mathrm{g} \cdot \mathrm{m}^{-1} \mathrm{EtBr}$, using $1 \mathrm{x}$ TAE electrophoresis buffer at $100 \mathrm{~V}$ for $1 \mathrm{~h}$, to determine whether amplification was successful.

\section{Sequencing of 16S rRNA}

The amplified PCR products (1 $200 \mathrm{bp}$ ) were purified using a High Pure PCR product purification kit, as per manufacturer's instructions (Roche Diagnostics GmbH, Mannheim, Germany). The concentrations of the DNA samples were determined using spectrophotometry and $15 \mu \ell$ of concentrated DNA (50 to 100 $\mathrm{ng} \cdot \mu \ell^{-1}$ depending on the length) samples were loaded onto 96-well microtitre plates, dried in a speed vac, with medium heat, for 30 to $60 \mathrm{~min}$ (depending on the volumes), and sent for sequencing. The sequencing lab used the Applied Biosystems Big Dye Terminator v3.1.

\section{Phylogenetic analysis}

The resultant sequences were identified with a similarity search 


\begin{tabular}{|l|c|c|c|}
\hline \multicolumn{4}{|c|}{$\begin{array}{c}\text { Metal concentrations obtained in water of the } \\
\text { Plankenburg River compared to recommended safe } \\
\text { concentrations as stipulated by DWAF (1996) and the } \\
\text { CCME (2001) }\end{array}$} \\
\hline Metal & $\begin{array}{c}\text { Recommended } \\
\text { safe } \\
\text { concentrations } \\
\text { as stipulated } \\
\text { by DWAF (1996) } \\
\left.\text { (mg. } \ell^{-1}\right)\end{array}$ & $\begin{array}{c}\text { Environmental } \\
\text { quality } \\
\text { guidelines as } \\
\text { stipulated by } \\
\text { CCME (2001) } \\
\left.\text { (mg. } \ell^{-1}\right)\end{array}$ & $\begin{array}{c}\text { Mean meal } \\
\text { concentrations } \\
\text { obtained } \\
\text { inater (mg. } \ell^{-1} \text { ) } \\
\text { (Plankenburg } \\
\text { River) }\end{array}$ \\
\hline $\mathrm{Al}$ & $0.1-0.15$ & $0.005-0.1$ & 11.56 \\
\hline $\mathrm{Cu}$ & $0.002-0.012$ & $0.002-0.004$ & 0.06 \\
\hline $\mathrm{Fe}$ & N/A & 0.3 & 12.2 \\
\hline $\mathrm{Mn}$ & 1.3 & N/A & 0.29 \\
\hline $\mathrm{Ni}$ & N/A & $0.025-0.15$ & 0.17 \\
\hline $\mathrm{Pb}$ & N/A & $0.001-0.007$ & 0 \\
\hline $\mathrm{Zn}$ & 0.036 & 0.03 & 0.4 \\
\hline
\end{tabular}

using Blastn from the National Centre for Biotechnology Information (NCBI) (Altschul et al., 1997). Contiguous sequences were formed for the forward and reverse sequences of a particular organism, using the CAP3 Sequence Assembly Programme (Huang and Madan, 1999). The contiguous sequences were aligned with ClustalX (1.81) (Higgins and Sharpe, 1988) using default parameters and the BLOSUM matrix, which corrects for multiple base changes. There were 37 organisms isolated overall, but many of the isolates were identical, therefore the 13 representative organisms on the tree were used for phylogenetic analyses. An unrooted tree was constructed using the neighbour-joining program of Saitou and Nei (1987). Phylogenetic analysis was conducted using Molecular Evolutionary Genetics Analysis, Version 3.1 (MEGA version 3.1) (Kumar and Nei, 2004). To estimate the node reliability, bootstrap values were obtained from 1000 randomlygenerated trees. Trees were visualised using MEGA version 3.1 (Kumar and Nei, 2004).

\section{Results and discussion}

\section{Metal concentrations in river water}

Inductively coupled plasma atomic emission spectrometry (ICP-AES) was used to determine the initial concentrations of metals in the collected river water prior to the flow cell set-up. These concentrations were compared to the Department of Water Affairs and Forestry (DWAF) (1996) and the Canadian Council of the Ministers of the Environment (CCME) (2001) recommended guidelines (Table 2). The $\mathrm{Al}, \mathrm{Cu}, \mathrm{Fe}, \mathrm{Ni}$ and $\mathrm{Zn}$ concentrations were $11.6 \mathrm{mg} \cdot \ell^{-1}, 0.06 \mathrm{mg} \cdot \ell^{-1}, 12.2 \mathrm{mg} \cdot \ell^{-1}, 0.17$ $\mathrm{mg} \cdot \ell^{-1}$ and $0.4 \mathrm{mg} \cdot \ell^{-1}$, respectively (Table 2 ). These concentrations were above the recommended concentrations as stipulated by DWAF (1996) and the CCME (2001). The Mn concentration of $0.29 \mathrm{mg} \cdot \ell^{-1}$, was below the recommended concentration of $1.3 \mathrm{mg} \cdot \ell^{-1}(1996)$.

\section{Flow cell experiment and image analysis}

Figures $3 \mathrm{~A}, 4 \mathrm{~A}, 5 \mathrm{~A}, 6 \mathrm{~A}, 7 \mathrm{~A}$ and $8 \mathrm{~A}$ represent the percentages of live and dead organisms (epifluorescence microscopy in conjunction with the ScionImage statistical programme) within the biofilm cultivated in the flow cells. In the graphs, the letter 'G' (green) indicates the live cells and the letter ' $\mathrm{R}$ ' (red) the dead cells. Figures $3 \mathrm{~B}, 4 \mathrm{~B}, 5 \mathrm{~B}, 6 \mathrm{~B}, 7 \mathrm{~B}$ and $8 \mathrm{~B}$ are images captured (untreated control and images captured after exposure to the respective metal concentrations) using epifluorescence microscopy. The results recorded in the control channels (which were left unexposed) showed that the initial percentages of live cells, for all of the metals analysed, were higher than that of the dead cells.

The following percentages were recorded for the channels exposed to Al concentrations: $48.12 \%$ alive $(\mathrm{G})$ and $43.21 \%$ dead $(\mathrm{R})$ for the control channels; $40.63 \%(\mathrm{G})$ and $47.68 \%(\mathrm{R})$ for the highest concentration of $900 \mathrm{mg} \cdot \ell^{-1} ; 42.31 \%(\mathrm{G})$ and $44.52 \%(\mathrm{R})$ for $500 \mathrm{mg} \cdot \ell^{-1}$, and $43.38 \%(\mathrm{G})$ and $42.59 \%(\mathrm{R})$ when exposed to $10 \mathrm{mg} \cdot \ell^{-1}$ (Figs. $3 \mathrm{~A}$ and $3 \mathrm{~B}$ ).

The percentages recorded for live and dead cells exposed to varying concentrations of $\mathrm{Cu}$ were: $44.02 \%(\mathrm{G})$ and $40.96 \%$
Figure $3 \boldsymbol{A}$ (right)

Percentages of living and dead organisms in response to exposure to various Al concentrations

Figure 3B (below)

Epifluorescent images of biofilm exposed to (i) Control, (ii) $900 \mathrm{mg} \cdot \ell^{-1} \mathrm{Al}$, (iii) 500 $\mathrm{mg} \cdot \ell^{-1} \mathrm{Al}$ and (iv) $10 \mathrm{mg} \cdot \ell^{1} \mathrm{Al}$
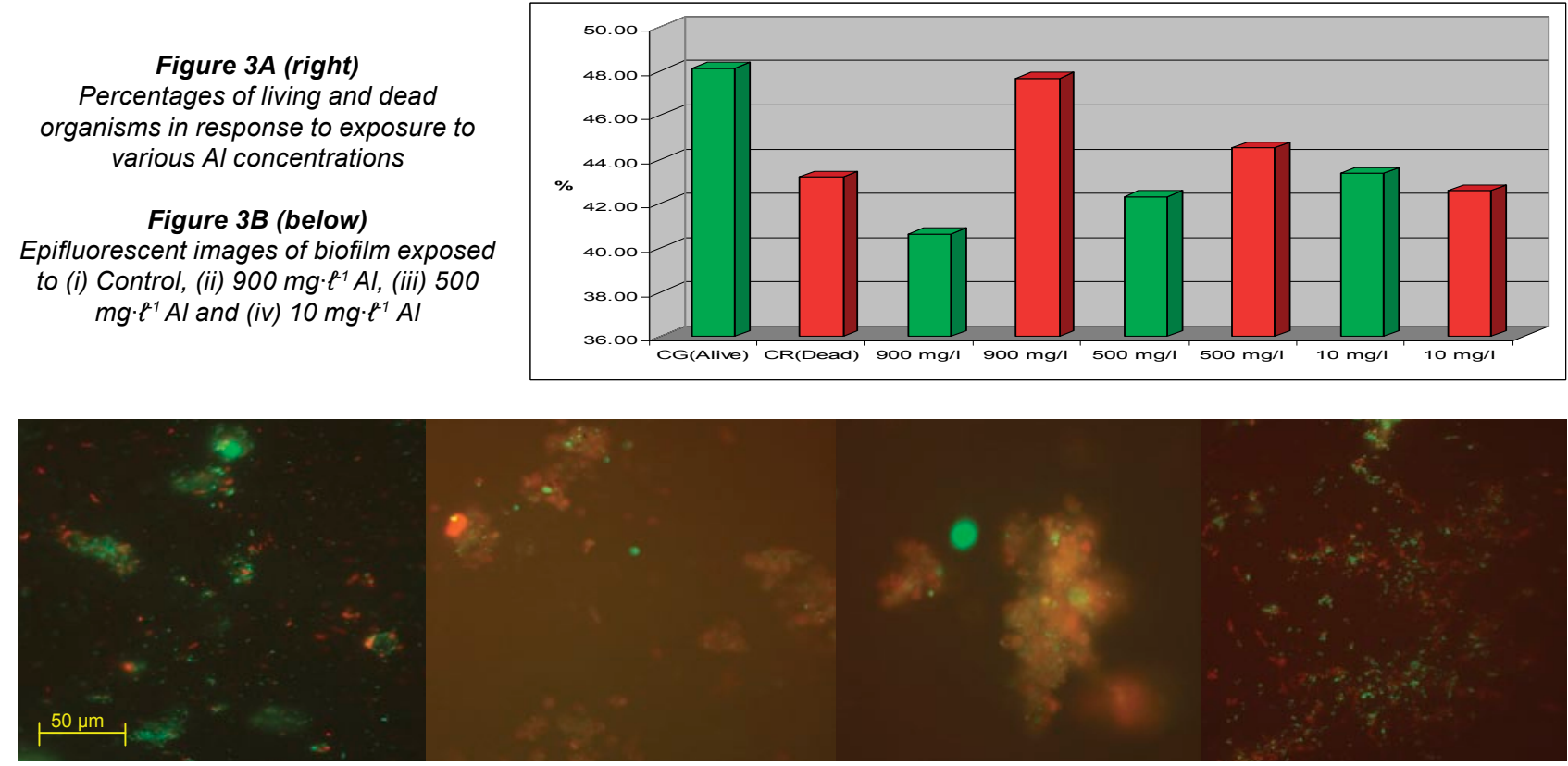

(i)

(ii)

(iii) 
Figure 4A (right)

Percentages of living and dead organisms in response to exposure

to various $\mathrm{Cu}$ concentrations

\section{Figure 4B (below)}

Epifluorescent images of biofilm exposed to (i) Control, (ii) $10 \mathrm{mg} \cdot \ell^{1}$

$\mathrm{Cu}$, (iii) $2.5 \mathrm{mg} \cdot \ell^{-1} \mathrm{Cu}$ and (iv) 0.5 $m g \cdot \ell^{-1} \mathrm{Cu}$
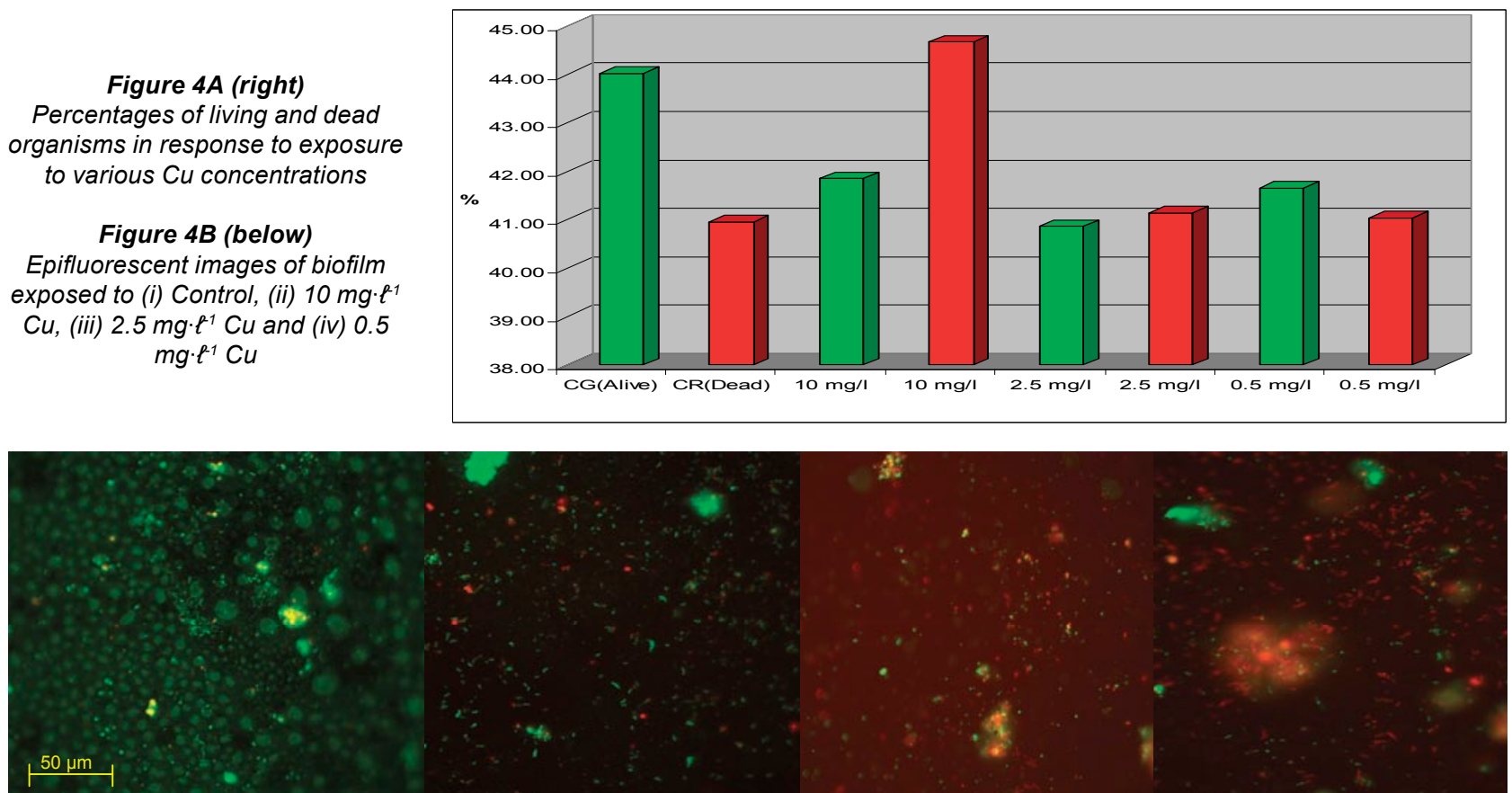

(i) (ii)

(iv)

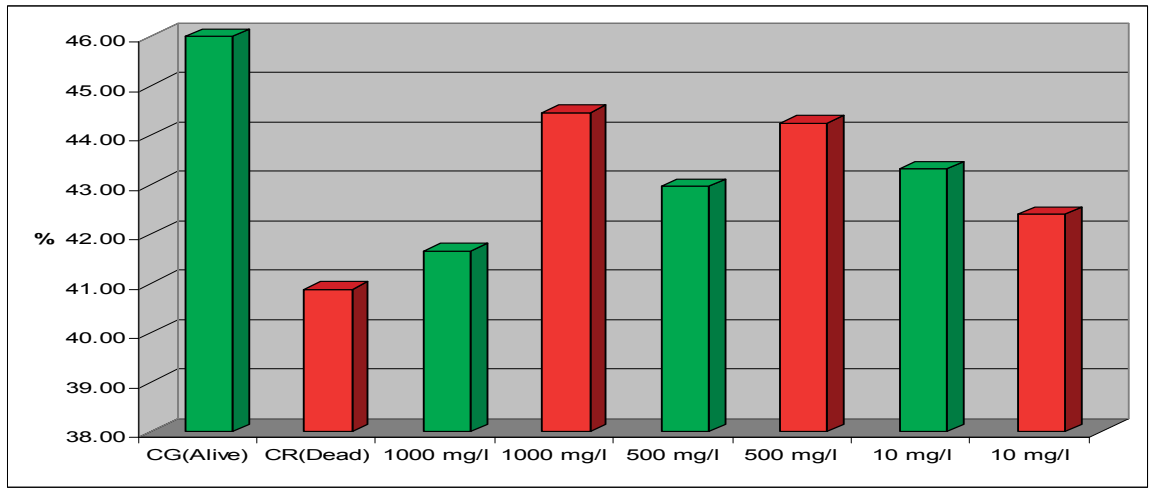

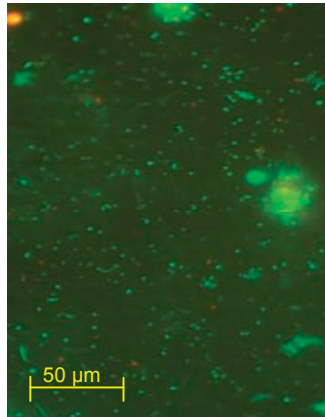

(i)

Represents the percentages of living and dead organisms in response to exposure to various $\mathrm{Fe}$ concentrations

\section{Figure 5B (below)}

Epifluorescent images of biofilm exposed to (i) Control, (ii) $1000 \mathrm{mg} \cdot \ell^{-1}$ $\mathrm{Fe}$, (iii) $500 \mathrm{mg} \cdot \ell^{-1} \mathrm{Fe}$ and (iv) $10 \mathrm{mg} \cdot \ell^{-1}$

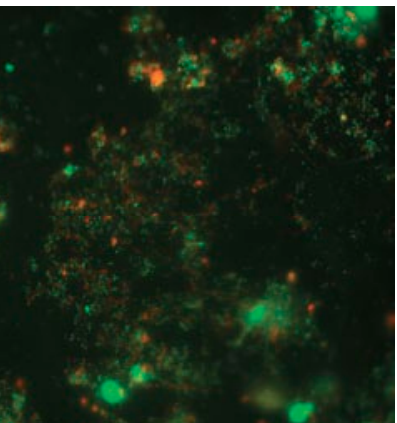

(iv)

(R) in the control channel; $41.85 \%(\mathrm{G})$ and $44.67 \%(\mathrm{R})$ for the highest concentration of $10 \mathrm{mg} \cdot \ell^{-1} ; 40.86 \%(\mathrm{G})$ and $41.14 \%(\mathrm{R})$ for $1 \mathrm{mg} \cdot \ell^{-1}$ and $41.66 \%(\mathrm{G})$ and $41.04 \%(\mathrm{R})$ when exposed to the lowest concentration of $0.5 \mathrm{mg} \cdot \ell^{-1}$ (Figs. 4A and 4B).

For $\mathrm{Fe}$, the ratio of live and dead cells in the untreated control was $46 \%$ live $(\mathrm{G})$ and $40.88 \%$ dead (R). The percentages obtained when the channels were exposed to the highest Fe concentration of $1000 \mathrm{mg} \cdot \ell^{-1}$ was $41.66 \%(\mathrm{G})$ and $44.47 \%$ (R); when exposed to $500 \mathrm{mg} \cdot \ell^{-1}$ the percentages were $42.96 \%$ (G) and $44.25 \%(\mathrm{R})$; and when exposed to the lowest concentration of $10 \mathrm{mg} \cdot \ell^{-1}$ the percentages recorded were $43.32 \%(\mathrm{G})$ and
$42.40 \%$ (R) (Figs. 5A and 5B).

The percentages of live and dead cells recorded after exposure to $\mathrm{Mn}$ in the untreated control were $43 \%(\mathrm{G})$ and $41.07 \%$ (R), respectively. Upon exposure to the highest concentration $\left(80 \mathrm{mg} \cdot \ell^{-1}\right)$, the number of live cells was $44.04 \%(\mathrm{G})$ and the number of dead cells was $50.23 \%(\mathrm{R})$. When exposed to the 2 lower concentrations of $15 \mathrm{mg} \cdot \ell^{-1}$ and $1.5 \mathrm{mg} \cdot \ell^{-1}$, the percentages of live and dead cells were $42.94 \%(\mathrm{G})$ and $43.39 \%(\mathrm{R})$ and $41.99 \%(\mathrm{G})$ and $41.18 \%(\mathrm{R})$, respectively (Figs. 6A and 6B).

The percentages of live and dead cells in the untreated flow cell control channels used to evaluate the various $\mathrm{Ni}$ 
Figure 6A (right)

Percentages of living and dead organisms in response to exposure to various $\mathrm{Mn}$ concentrations

Figure 6B (below)

Epifluorescent images of biofilm exposed to (i) Control, (ii) $80 \mathrm{mg} \cdot \ell^{-1} \mathrm{Mn}$, (iii) $15 \mathrm{mg} \cdot \ell^{-1} \mathrm{Mn}$ and (iv) $1.5 \mathrm{mg} \cdot \ell^{-1} \mathrm{Mn}$
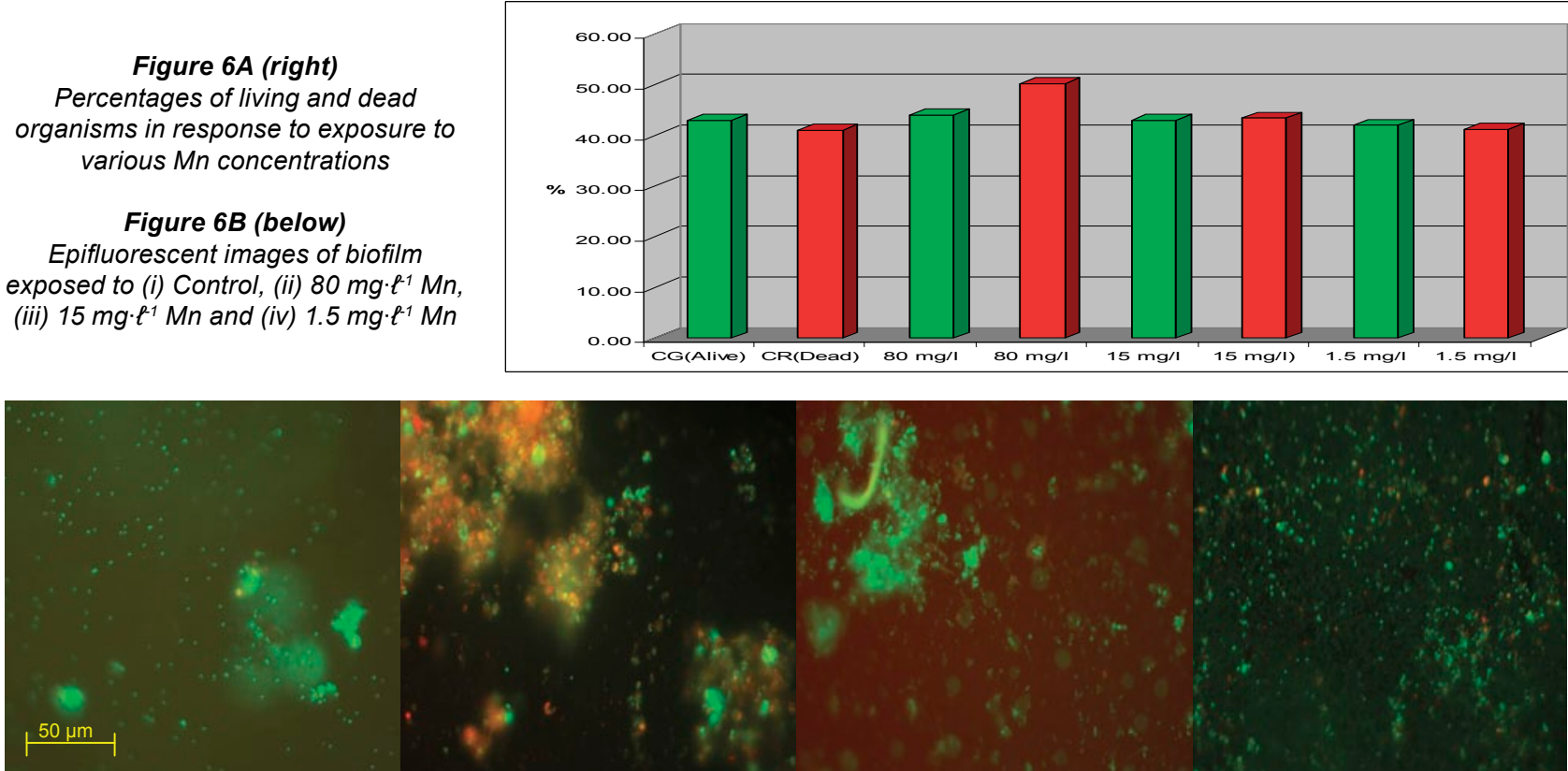

(i)
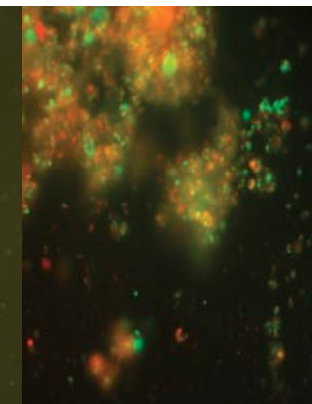

(ii)

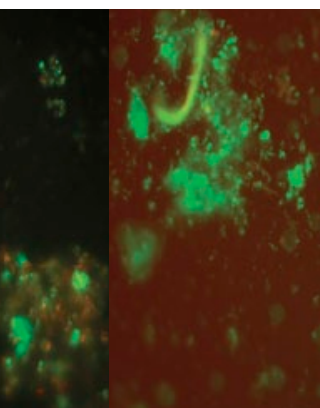

(iii)

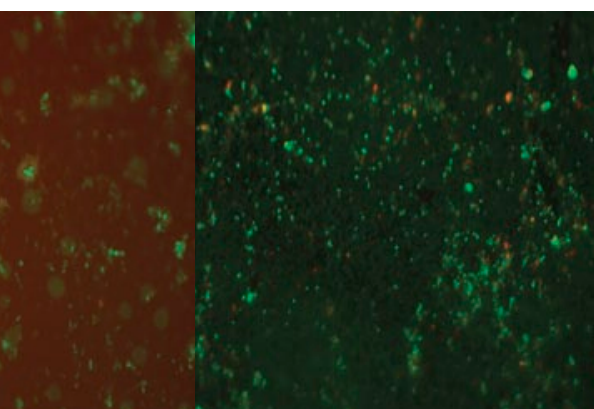

(iv)
Figure 7A (right)

Percentages of living and dead organisms in response to exposure to various Ni concentrations

\section{Figure 7B (below)}

Epifluorescent images of biofilm exposed to (i) Control, (ii) $20 \mathrm{mg} \cdot \ell^{-1} \mathrm{Ni}$, (iii) $1 \mathrm{mg} \cdot \ell^{-1} \mathrm{Ni}$ and (iv) $0.5 \mathrm{mg} \cdot \ell^{-1} \mathrm{Ni}$

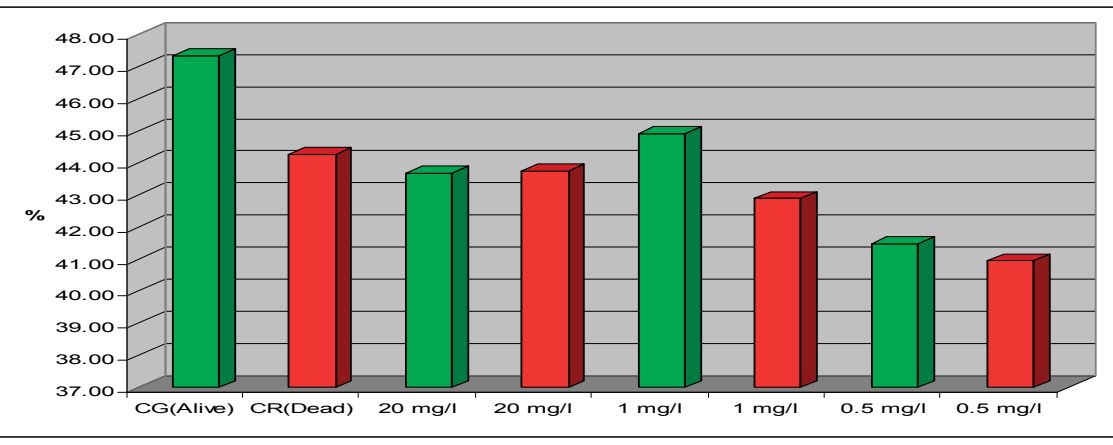

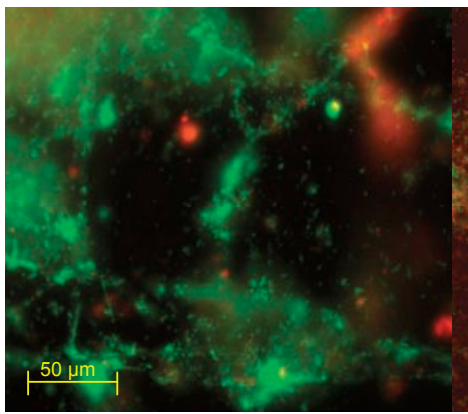

(i)

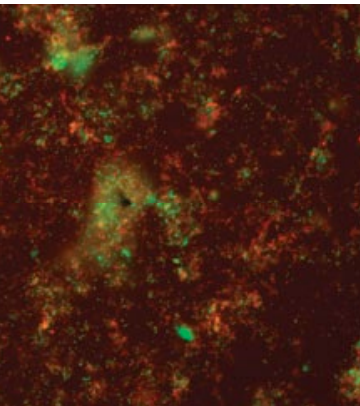

(ii)

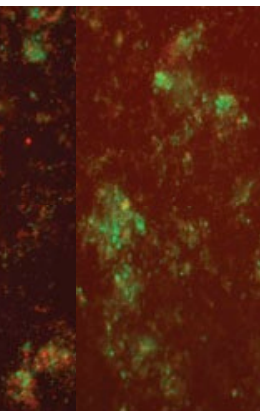

(iii)

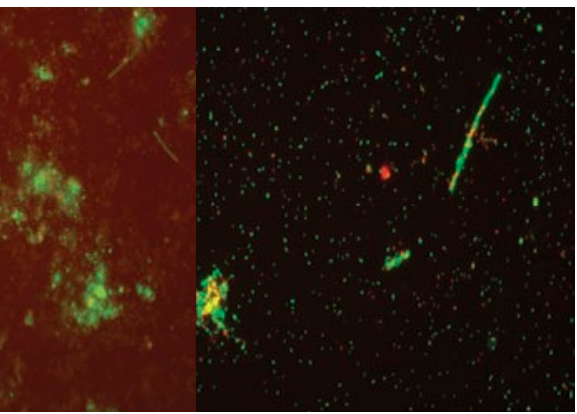

(iv) concentrations were $47.34 \%(\mathrm{G})$ and $44.27 \%(\mathrm{R})$, respectively. The percentages recorded in the channels exposed to the highest $\mathrm{Ni}$ concentration of $20 \mathrm{mg} \cdot \ell^{-1}$ were $43.68 \%(\mathrm{G})$ and $43.75 \%$ $(\mathrm{R})$, while the percentages recorded when exposed to $1 \mathrm{mg} \cdot \ell^{-1}$ were $44.91 \%(\mathrm{G})$ and $42.89 \%(\mathrm{R})$; when exposed to $0.5 \mathrm{mg} \cdot \ell^{-1}$, $41.49 \%$ of the cells were alive $(\mathrm{G})$ and $40.95 \%$ of the cells were dead (R) (Figs. 7A and 7B).

The channels exposed to the varying $\mathrm{Zn}$ concentrations yielded the following results in the untreated control channel: $45.06 \%$ live cells $(\mathrm{G})$ and $41.32 \%$ dead cells (R). The percentages recorded in the flow cell channels exposed to the highest $\mathrm{Zn}$ concentrations $\left(40 \mathrm{mg} \cdot \ell^{-1}\right)$ were $41.27 \%(\mathrm{G})$ and $41.82 \%(\mathrm{R})$, while the percentages recorded when exposed to $1 \mathrm{mg} \cdot \ell^{-1}$ were
$41.37 \%(\mathrm{G})$ and $41.44 \%(\mathrm{R})$. The percentages recorded when exposed to $0.5 \mathrm{mg} \cdot \ell^{-1}$ wrtr $42.58 \%(\mathrm{G})$ and $41.15 \%(\mathrm{R})$, respectively (Figs. $8 \mathrm{~A}$ and $8 \mathrm{~B}$ ).

When compared to the untreated controls, the percentages obtained in the channels of the flow cells exposed to the highest concentrations of $\mathrm{Al}\left(900 \mathrm{mg} \cdot \ell^{-1}\right), \mathrm{Cu}\left(10 \mathrm{mg} \cdot \ell^{-1}\right), \mathrm{Fe}(1000$ $\left.\mathrm{mg} \cdot \ell^{-1}\right)$ and $\mathrm{Mn}\left(80 \mathrm{mg} \cdot \ell^{-1}\right)$ (Figs. 3A, 4A, 5A, 6A) showed an increase in the number of dead cells of $4.47 \%, 3.71 \%, 3.59 \%$ and $9.16 \%$, respectively. When the channels were exposed to the lowest concentrations of $10 \mathrm{mg} \cdot \ell^{-1}(\mathrm{Al}), 0.5 \mathrm{mg} \cdot \ell^{-1}(\mathrm{Cu}), 1.5$ $\mathrm{mg} \cdot \ell^{-1}(\mathrm{Mn})$ and $0.5 \mathrm{mg} \cdot \ell^{-1}(\mathrm{Zn})$, the ratio of live to dead cells was similar to that of the untreated control. When exposed to the highest concentrations of $\mathrm{Zn}\left(40 \mathrm{mg} \cdot \ell^{-1}\right)$ and $\mathrm{Ni}\left(20 \mathrm{mg} \cdot \ell^{-1}\right)$ 
Figure 8A (right)

Percentages of living and dead organisms in response to exposure to various $\mathrm{Zn}$ concentrations

Figure 8B (below)

Epifluorescent images of biofilm exposed $\mathrm{Zn}$ and (iv) $0.5 \mathrm{mg} \cdot \ell^{-1} \mathrm{Zn}$ to (i) Control, (ii) $40 \mathrm{mg} \cdot \ell^{-1} \mathrm{Zn}$, (iii) $1 \mathrm{mg} \cdot \ell^{-1}$
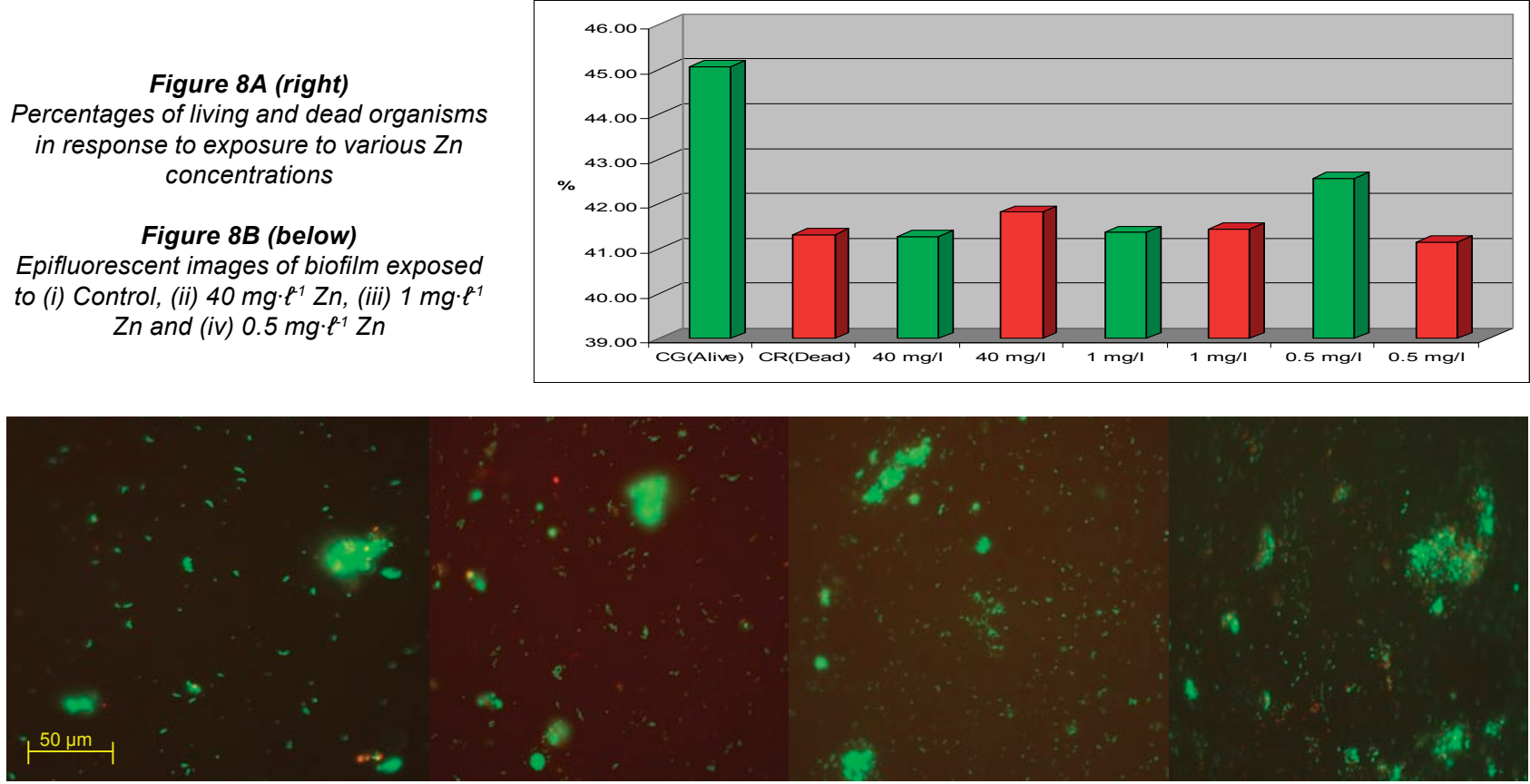

(i)

(ii)

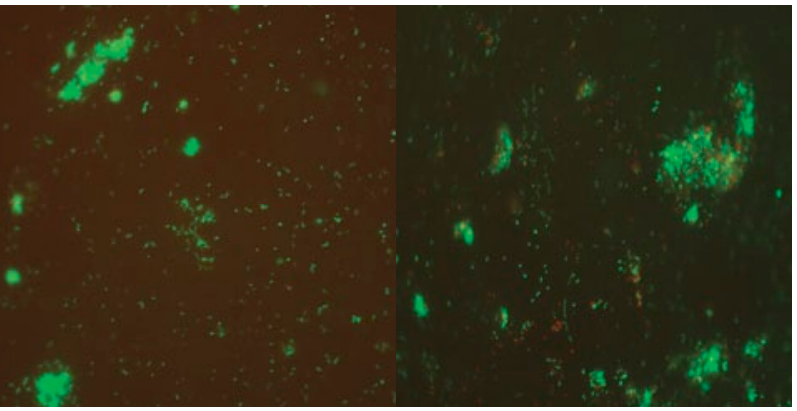

(iii)
Figure 9 (right)

Agarose gel electrophoresis photograph of the PCR products obtained with 16 SrRNA universal forward and reverse primers (fDD2 and rPP2) of organisms isolated from flow cells after exposure to varying metal concentrations. Lane 1 represents the marker (Lambda DNA/HindIII), Lane 2, the negative control, and Lanes 3 to 20 represent the selected isolates showing the $1200 \mathrm{bp}$ amplicons.

no significant differences between the live and dead cell percentages were observed, as the percentages of dead cells only decreased by $0.52 \%$ and $0.5 \%$, respectively (Figs. $7 \mathrm{~A}$ and $8 \mathrm{~A}$ ). In a previous study, conducted by Bhadra et al. (2007), high concentrations of metals ( $\mathrm{Zn}$ and $\mathrm{Ni}$ ) in the river water affected the numbers of $\mathrm{Zn}$ - and Ni-resistant bacteria; the higher metal concentrations resulted in an increase in resistance mechanisms of the isolates. Table 2 presents the metal concentrations recorded in the water samples. The initial $\mathrm{Zn}$ concentration in the river water prior to treatment was $0.4 \mathrm{mg} \cdot \ell^{-1}$, which was significantly higher $(p<0.05)$ than the recommended guidelines of $0.036 \mathrm{mg} \cdot \ell^{-1}$ (DWAF, 1996) and $0.03 \mathrm{mg} \cdot \ell^{-1}$ (CCME, 2001). The initial $\mathrm{Ni}$ concentration in the river water prior to treatment was $0.17 \mathrm{mg} \cdot \ell^{-1}$, which was significantly higher $(p<0.05)$ than the recommended guideline of $0.025 \mathrm{mg} \cdot \ell^{-1}$ to $0.15 \mathrm{mg} \cdot \ell^{-1}$ (CCME, 2001).

In the case of exposure of the respective flow cell channels to the highest $\mathrm{Al}$ and Fe concentrations, Figs. 3B and 5B show that the organisms tended to clump together in response to the metal exposure. The ability of extracellular polymeric substances to bind metals and pollutants also contributes to the clumping of cells (McMlean et al., 1990). Previous research performed by Teitzel and Parsek (2003) showed that cells at the biofilm-bulk liquid interface were exposed to the high concentrations of various metals. According to Harrison et al. (2007), metabolic gradients in solid-surface-attached biofilms can result in the non-uniform distribution of extracellular $\mathrm{pH}$, which in turn restricts the microbial growth rates in certain portions of the biofilm. The differences created by metabolic gradients and extracellular $\mathrm{pHs}$ contribute to the varying physiological states of the organisms within the biofilm; because the zones closest to the substratum are anoxic, the growth rates of organisms in these zones are slow and they are therefore more resistant to metals. The 2 fluorophores used (SYTO 9 and Propidium Iodide) stain the living cells green and the dead cells red, respectively. When the cells fluoresce yellow, it means that the 2 images are superimposed and it is impossible to distinguish live cells from dead cells (Figs. 3B to 8B). Teitzel and Parsek (2003) also reported that, in minimal media with short exposure times, biofilms have a demonstrable resistance to the heavy metals $\mathrm{Cu}^{2+}, \mathrm{Zn}^{2+}$ and $\mathrm{Pb}^{2+}$.

\section{Polymerase chain reaction (PCR) and sequencing of 16SrRNA}

Table 3 represents the names of organisms isolated from the flow cells after exposure to varying metal concentrations. An agarose gel electrophoresis photograph showing selective results of the PCR fragments (1 $200 \mathrm{bp})$ is presented in Fig. 9. Figure 9 clearly shows that the $1200 \mathrm{bp} \mathrm{PCR}$ amplicon was routinely amplified. Overall, 37 organisms were isolated, but many of the isolates were identical; therefore, only 13 organisms were used in the construction of the phylogenetic tree. 
Table 3

Table of 13 isolates, their names presented on the phylogenetic tree and accession numbers

\begin{tabular}{|c|c|c|}
\hline Name presented on tree & Organism & Accession \# \\
\hline 12A 10 Pseudomonas sp. & Pseudomonas sp. 12A_10 & gb|AY689075.1| \\
\hline TC222 P. fluorescens isolate & Pseudomonas fluorescens isolate TC222 & dbi|AB238774.1 \\
\hline 12A Pseudomonas sp. & Pseudomonas sp. 12A & gb|AY689075.1 \\
\hline A90 D. tsuruhatensis st & Delftia tsuruhatensis strain A90 & $\mathrm{gb}|\mathrm{EF} 421404.1|$ \\
\hline RRLJSMAR P. beteli $\mathrm{st}$ & Pseudomonas beteli strain RRLJ SMAR & $\mathrm{gb}|\mathrm{DQ} 299947.1|$ \\
\hline 776 S. maltophilia st & Stenotrophomonas maltophilia strain 776 & gb|EU430096.1| \\
\hline 8b-1 Sphingomonas sp. & Sphingomonas sp. $8 \mathrm{~b}-1$ & $\mathrm{gb} \mid \mathrm{DQ} 378211.1$ \\
\hline WDL7 C. testosteroni & Comamonas testosteroni WDL7 & AF538929 \\
\hline ZH6 Bacillus sp. & Bacillus sp. ZH6 & $\mathrm{gb} \mid \mathrm{EU} 236752.1$ \\
\hline MOLA 313 Staphylococcus sp. & Staphylococcus sp. MOLA:313 & emb|AM945546.1 \\
\hline PAO-12 Microbacterium sp. & Microbacterium sp. PAO-12 & gb|EF514877.1| \\
\hline TPR1 Micrococcus sp. & Micrococcus sp. TPR14 & gb|EU373424.1 \\
\hline 6J-5b K. kristinae st & Kocuria kristinae strain $6 \mathrm{~J}-5 \mathrm{~b}$ & gb|EU379300.1| \\
\hline
\end{tabular}

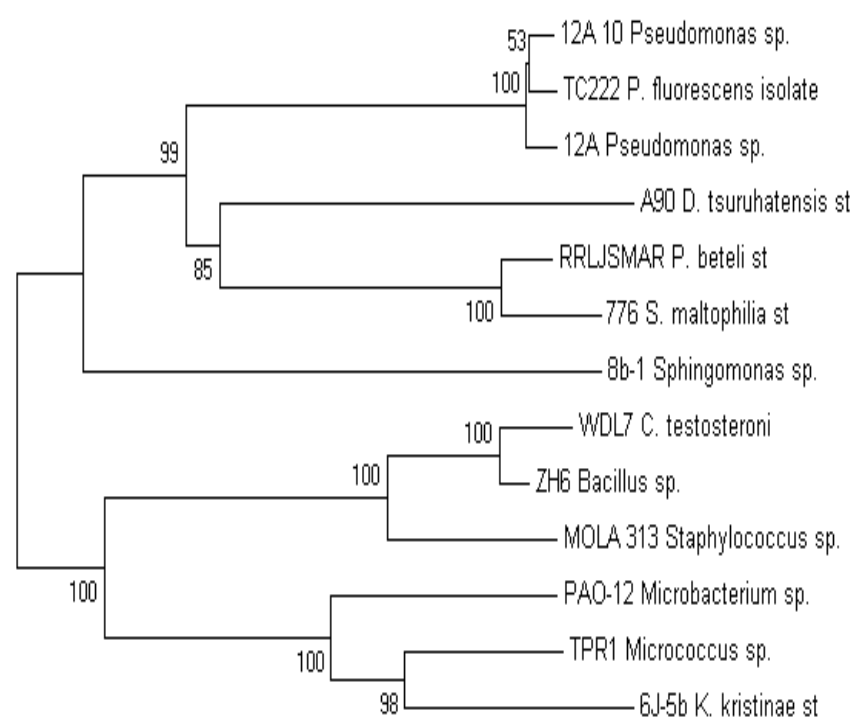

0.02

Figure 10

An unrooted phylogenetic tree of organisms isolated from flow cells after exposure to varying metal concentrations. The tree of 13 isolates was formed using the neighbour-joining algorithm of ClustalX. Bootstrap values are shown at the nodes.

The phylogeny of the 13 representative organisms in GenBank (www.ncbi.nlm.nih/gov/Genban/submit.html) were analysed using the neighbour-joining algorithm in ClustalX (Fig. 10). The tree was aligned to determine evolutionary relatedness between the various isolates.

\section{Phylogenetic analysis}

Most of the isolates from all of the channels were identified as Staphylococcus sp. MOLA:313, Delftia tsuruhatensis strain A90, Pseudomonas fluorescens isolate TC222, Pseudomonas beteli strain RRLJ SMAR, Bacillus sp. ZH6 and Stenotrophomonas maltophilia strain 776. Two major clusters could be distinguished from the tree (Fig. 10) based on their Gram-reaction. From the phylogenetic tree it could be seen that the Gram-negative organisms, Proteobacteria (Pseudomonas sp., and Stenotrophomonas sp.) clustered together, whereas the Gram-positive organisms, low and high $\mathrm{G}+\mathrm{C}$ Gram-positives (Bacillus sp., Micrococcus sp. and Microbacterium sp.), clustered together. In the first cluster, 2 clades could clearly be distinguished; the first clade consisted of Pseudomonas sp. and the second clade of a Pseudomonas sp. and a Stenotrophomonas sp. The isolates, Delftia tsuruhatensis st. A90 and Sphingomonas sp. 8b-1, were rooted to Clades 1 and 2, but, judging by the length of the nodes, did not seem to belong to any of the groups. In the second cluster, 2 distinct clades could be distinguished. The first clade consisted of WDL7 Comamonas testosterone, ZH6 Bacillus sp. and MOLA 313 Staphylococcus sp. The second clade consisted of TPR1 Micrococcus sp., 6J-5b Kocuria kristinae st and PAO-12 Microbacterium sp.

In previous research it was shown that several Grampositive (Arthrobacter sp. and Corynebacterium sp.) and Gram-negative (Alcaligenes sp.) organisms were shown to be resistant to $\mathrm{Pb}, \mathrm{Hg}, \mathrm{Cd}, \mathrm{Cu}, \mathrm{Co}$ and $\mathrm{Zn}$ (Trajanovska et al., 1997), which could be correlated with the results obtained in the present study. The major difference between the 2 clusters was that the Gram-positive organisms, Staphylococcus MOLA:313, Micrococcus sp. TPR1 and Kocuria kristinae st. $6 \mathrm{~J}-5 \mathrm{~b}$, were resistant to Mn (Fig. 10 and Table 4), and that the clade consisting of the Pseudomonas sp. all exhibited tolerance to Ni exposure. Table 4 represents the organisms isolated from the different flow cells after exposure to the varying metal concentrations. The organisms in the table below were present after exposure to $\mathrm{Al}, \mathrm{Cu}, \mathrm{Fe}, \mathrm{Mn}, \mathrm{Ni}$ and $\mathrm{Zn}$ concentrations and were presumed to be metal-tolerant organisms. Organisms such as Comamonas testosteroni WDL7, Microbacterium sp. PAO-12, Sphingomonas sp. 8b-1, Kocuria kristinae strain 6J-5b and Micrococcus sp. TPR14 exhibited tolerance to specific metals, which included $\mathrm{Cu}, \mathrm{Ni}$, $\mathrm{Zn}$ and $\mathrm{Mn}$, respectively (Table 4 ). The other isolates showed resistance to a range of different metals.

In a previous study by Bhadra et al. (2007), Pseudomonas, Bacillus, Moraxella, Enterobacter, Serratia, Morganella and Acinetobacter species were used to study Ni and $\mathrm{Zn}$ resistance, as these organisms possess inducible Ni- or Zn-resistance genetic systems. Their results indicated that the $\mathrm{Ni}$ and $\mathrm{Zn}$ resistance was induced at concentrations as low as $0.3 \mathrm{mg} \cdot \ell^{-1}$ $\mathrm{Zn}^{2+}$ for Ni resistance in Pseudomonas sp. and $\mathrm{Zn}$ resistance was 


\begin{tabular}{|c|c|}
\hline \multicolumn{2}{|c|}{$\begin{array}{l}\text { Table } 4 \\
\text { Isolated organisms and the metals to which they were exposed }\end{array}$} \\
\hline Microorganisms & Metals \\
\hline Comamonas testosteroni WDL7 & $\mathrm{Cu}$ \\
\hline Microbacterium sp. PAO-12 & $\mathrm{Ni}$ \\
\hline Sphingomonas sp. 8b-1 & $\mathrm{Zn}$ \\
\hline Kocuria kristinae strain $6 \mathrm{~J}-5 \mathrm{~b}$ & $\mathrm{Mn}$ \\
\hline Micrococcus sp. TPR14 & $\mathrm{Mn}$ \\
\hline $\begin{array}{l}\text { Pseudomonas beteli strain RRLJ SMAR, Pseudomonas sp. } 12 \mathrm{~A} \text {, } \\
\text { Pseudomonas fluorescens isolate TC222, Pseudomonas sp. } 12^{\mathrm{A}}{ }_{2} \text {. }\end{array}$ & $\mathrm{Cu}, \mathrm{Ni}$ \\
\hline Delftia tsuruhatensis strain A90 & $\mathrm{Ni}, \mathrm{Cu}$ \\
\hline Bacillus sp. ZH6 & $\mathrm{Zn}, \mathrm{Ni}, \mathrm{Al}, \mathrm{Fe}$ \\
\hline Staphylococcus sp. MOLA:313 & $\mathrm{Zn}, \mathrm{Mn}, \mathrm{Al}, \mathrm{Fe}$ \\
\hline Stenotrophomonas maltophilia strain 776 & $\mathrm{Zn}, \mathrm{Ni}, \mathrm{Cu}, \mathrm{Al}, \mathrm{Fe}$ \\
\hline
\end{tabular}

inducible by a concentration as low as $0.25 \mathrm{mg} \cdot \ell^{-1} \mathrm{Zn}^{2+}$.

The clusters also contained more Gram-negative than Gram-positive organisms (Fig. 10). Yilmaz (2004) and others have suggested that Gram-negative organisms predominate in metal-polluted environments, and also showed that it was reasonable to expect a certain degree of overlap between Grampositive and Gram-negative bacteria, as some of these species are resistant to the same metals.

After the metals bind to the organism, they must either cross the cell wall of the Gram-positive organism or the outer membrane of the Gram-negative organism. Studies on $\mathrm{Cu}-$, Cd-, Zn-, Cr-, Ni- and As-resistant bacteria have identified metal resistance genes located on the plasmid which can be induced in the presence of the particular metal (Trajanovska et al., 1997).

Bacillus, Pseudomonas, Xanthomonas, Stenotrophomonas, Sphingomonas sp. and Janthinobacterium lividum, were shown to display resistance to $\mathrm{Zn}$, Bacillus sp. was shown to be resistant to $\mathrm{Cu}$, while Variovorax $\mathrm{sp}$. was shown to be resistant to silver $(\mathrm{Ag}), \mathrm{Zn}$ and $\mathrm{Cu}$ (Piotrowska-Seget et al., 2005). In the present study, isolates such as Comamonas testosteroni WDL7 showed resistance to $\mathrm{Cu}$, Kocuria kristinae strain 6J-5b showed resistance to Mn, and Bacillus sp. ZH6, Stenotrophomonas maltophilia strain 776 and Staphylococcus sp. MOLA:313 all showed resistance to Al, Fe and Zn (Table 4).

Piotrowska-Seget et al. (2005) studied metal-tolerant bacteria occurring in heavily-polluted soil and mine spoil in Katowice, Poland. The authors performed minimum inhibitory concentration studies to determine the resistance mechanisms of the different bacterial isolates. They found that Pseudomonas gladioli was resistant to $\mathrm{Zn}$ and $\mathrm{Cu}$ concentrations of 10 $\mathrm{mM}$ and $5 \mathrm{mM}$, respectively. In the present study the isolate Pseudomonas beteli str. RRLJSMAR showed resistance to $\mathrm{Cu}$ concentrations. Another study, conducted by Chien et al. (2007), evaluated the bacterial diversity in soil in order to determine bacterial response to media amended with $\mathrm{Cd}, \mathrm{Cr}$, $\mathrm{Ni}, \mathrm{Zn}, \mathrm{Pb}$, and $\mathrm{Cu}$. Stenotrophomonas sp., isolated from a site contaminated with high concentrations of $\mathrm{Cd}\left(3 \mathrm{mg} \cdot \mathrm{kg}^{-1}\right)$ and $\mathrm{Cr}$ (115 mg.kg-1), was able to grow on media containing $\mathrm{Cd}$ concentrations of up to $4 \mathrm{mM}$, and was also able to remove up to $80 \%$ dissolved ions upon completion of the stationary growth phase. In addition it was also able to resist other metals, such as, $\mathrm{Cu}, \mathrm{Cr}$, $\mathrm{Ni}, \mathrm{Pb}$ and $\mathrm{Zn}$, at levels of more than $2 \mathrm{mM}$ Chien et al. (2007).

Three Bacillus isolates (B. cereus, B. megaterium and $B$. sphaericus), recovered from a uranium waste pile in Germany, were evaluated for their ability to accumulate metals, including $\mathrm{Al}, \mathrm{Cd}, \mathrm{Cu}, \mathrm{Fe}, \mathrm{Mn}, \mathrm{Ni}, \mathrm{Pb}$, and $\mathrm{Zn}$, amongst others.
Results revealed that the Bacillus sp. were able to accumulate large amounts of $\mathrm{Pb}, \mathrm{Cd}, \mathrm{Cu}, \mathrm{Al}, \mathrm{Mn}, \mathrm{Ni}$ and $\mathrm{Zn}$ (SelenskaPobell et al., 2006).

Yilmaz (2004) showed that Bacillus circulans could tolerate high concentrations of $\mathrm{Cu}, \mathrm{Mn}, \mathrm{Ni}, \mathrm{Zn}, \mathrm{Co}$ and $\mathrm{Cd}$, and that the increased metal resistance resulted in a decrease in bacterial growth. The present study showed that different microorganisms with the ability to resist varying concentrations of metals were isolated from the treated flow cells following metal exposure. Isolates, such as Pseudomonas sp., Bacillus sp. and Staphylococcus sp., were shown to be tolerant to a wider range of metals ( $\mathrm{Cu}, \mathrm{Mn}, \mathrm{Ni}, \mathrm{Zn}, \mathrm{Al}$ and $\mathrm{Fe})$, while others, such as Comamonas testosteroni WDL7 and Kocuria kristinae strain $6 \mathrm{~J}-5 \mathrm{~b}$, showed resistance to only $\mathrm{Cu}$ and $\mathrm{Mn}$, respectively. These organisms can thus potentially be employed for future use in remediation processes.

\section{Conclusions}

- With the exception of Mn, the initial metal concentrations recorded in the water samples were above the recommended concentrations as stipulated by DWAF (1996) and the CCME (2001).

- Based on ScionImage analysis, no significant differences between the percentages of live and dead cells could be observed when the flow cell channels were exposed to the lowest concentrations of $10 \mathrm{mg} \cdot \ell^{-1}(\mathrm{Al}), 0.5 \mathrm{mg} \cdot \ell^{-1}(\mathrm{Cu}), 1.5$ $\mathrm{mg} \cdot \ell^{-1}(\mathrm{Mn})$ and $0.5 \mathrm{mg} \cdot \ell^{-1}(\mathrm{Zn})$.

- In addition, the ratio of live to dead cells in the flow cell channels exposed to the lowest metal concentration was similar to that recorded in the untreated control.

- The highest percentage of dead cells was recorded in the flow cell channels exposed to the highest metal concentrations (Al (900 mg. $\left.\ell^{-1}\right), \mathrm{Fe}\left(1000 \mathrm{mg} \cdot \ell^{-1}\right), \mathrm{Cu}\left(10 \mathrm{mg} \cdot \ell^{-1}\right)$ and Mn $\left.\left(80 \mathrm{mg} \cdot \ell^{-1}\right)\right)$.

- The percentages of dead cells recorded did not differ significantly from the percentages of live cells after exposure to the highest concentrations of $\mathrm{Zn}\left(40 \mathrm{mg} \cdot \ell^{-1}\right)$ and $\mathrm{Ni}(20$ mg. $\left.\ell^{-1}\right)$.

- The phylogenetic tree showed that the organisms isolated from the flow cell experiment after exposure to various metal concentrations were diverse.

- Some of the isolates were isolated from channels exposed to various metals and exhibited multiple metal resistance, while others were only isolated from specific metal channels and therefore showed resistance to specific metals. 
- Stenotrophomonas maltophilia strain 776 exhibited tolerance to $\mathrm{Zn}, \mathrm{Ni}, \mathrm{Cu}, \mathrm{Al}$ and $\mathrm{Fe}$, while Bacillus sp. ZH6 showed tolerance to $\mathrm{Zn}, \mathrm{Ni}, \mathrm{Al}$ and $\mathrm{Fe}$ and Staphylococcus sp. MOLA:313 exhibited tolerance to $\mathrm{Zn}, \mathrm{Mn}, \mathrm{Al}$ and $\mathrm{Fe}$ exposure.

- Comamonas testosteroni WDL7, Microbacterium sp. PAO12 , Sphingomonas sp. $8 \mathrm{~b}-1$, showed tolerance for $\mathrm{Cu}, \mathrm{Ni}$ and $\mathrm{Zn}$, respectively, while Kocuria kristinae strain $6 \mathrm{~J}-5 \mathrm{~b}$ and Micrococcus sp. TPR14 exhibited tolerance to Mn.

- The major metal-resistant organisms, Bacillus sp. and Pseudomonas sp., both displayed resistance to Ni. Bacillus sp., however, also showed resistance to $\mathrm{Zn}, \mathrm{Al}$ and $\mathrm{Fe}$, while Pseudomonas sp. showed resistance to $\mathrm{Cu}$.

\section{Acknowledgements}

The National Research Foundation (NRF) and Cape Peninsula University of Technology (CPUT) are thanked for financial support.

\section{References}

ALLINOR IJ (2005) Assessment of elemental contaminants in water and fish samples from Aba River. Environ Monit Assess. 2 (1-3) 15-25.

ALTSCHUL SF, MADDEN TL, SCHÄFFER AA, ZHANG J, ZHANG Z, MILLER W and LIPMAN DJ (1997) Gapped BLAST and PSI-BLAST: a new generation of protein database search programs. Nucleic Acids Res. 25 3389-3402.

AMANN RI, LUDWIG W and SCHLEIFER KH (1995) Phylogenetic identification and in situ detection of individual microbial cells without cultivation. Microbiol. Res. 59 143-169.

BHADRA B, NANDA AK and CHAKRABORTY R (2007) Fluctuation in recoverable nickel and zinc resistant copiotrophic bacteria explained by the varying zinc ion content of Torsa River in different months. Arch. Microbiol. 188 215-224.

BOULOS L, PRÉVOST M, BARBEAU B, COALLIER J and DESJARDINS R (1999) LIVE/DEAD ${ }^{\circledR}$ BacLight ${ }^{\mathrm{TM}}$ : application of a new rapid staining method for direct enumeration of viable and total bacteria in drinking water. J. Microbiol. Meth. 37 77-86.

CALDWELL DE, WOLFAARDT GM, KORBER DR, KAARTHIKEYAN S and LAWRENCE JR (2002) Cultivation of microbial communities. In: Hurst CJ, Crawford RL, Knudsen GR, McInerney MJ, Stetzenbach LD (eds.) Manual for Environmental Microbiology. ASM Press, San Diego, USA. 92-100.

CCME (CANADIAN COUNCIL OF THE MINISTERS OF THE ENVIRONMENT) (2001) Canadian sediment quality guidelines for the protection of aquatic life: Summary tables. Updated in: Canadian Environmental Quality Guidelines. Canadian Council of Ministers of the Environment, Winnipeg, Canada.

CHIEN CC, HUNG CW and HAN CT (2007) Removal of cadmium ions during stationary growth phase by an extremely cadmium resistant strain of Stenotrophomonas sp. Environ. Toxicol. Chem. 26 664-668.

DEAT (DEPARTMENT OF ENVIRONMENTAL AFFAIRS AND TOURISM, SOUTH AFRICA) (1996) National Waste Management Strategy Implementation Project. URL: http://www.environment. gov.za/nwmsi/background/planning legreview-starterdoc.pdf. (Accessed 12 March 2007).

DEPARTMENT OF WATER AFFAIRS AND FORESTRY (DWAF) (1996) South African Water Quality Guidelines for Fresh Water $2^{\text {nd }}$ Edition, Domestic Water Use. Environmental Services, CSIR, Pretoria. 77-87

HARRISON JJ, CERI H and TURNER RJ (2007) Multimetal resistance and tolerance in microbial biofilms. Nat. Rev. Microbiol. 5 (12) 928-933.
HIGGINS DG and SHARPE PM (1988) CLUSTAL: a package for performing multiple sequence alignment on a microcomputer. Gene 73 237-244.

HUANG X and MADAN A (1999) CAP3: A DNA sequence assembly program. Genome Res. 9 868-877.

JACKSON VA, PAULSE AN, ODENDAAL JP and KHAN W (2009) Investigation into the metal contamination of the Plankenburg- and Diep Rivers, Western Cape, South Africa. Water SA 35 (3) 1-11.

KUMAR S, TAMURA K and NEI M (2004) MEGA3: Integrated software for molecular evolutionary genetics analysis and sequence alignment. Brief Bioinform. 5 150-163.

MAANAN M, ZOURARAH B, CARRUESCO C, AAJJANE A and NAUD J (2004) The distribution of heavy metals in the Sidi Moussa lagoon sediments (Atlantic Moroccan Coast). J. Afr. Earth Sci. 39 473-483.

MARTIN AP (2002) Phylogenetic approaches for describing and comparing the diversity of microbial communities. Appl. Environ. Microbiol. 68 (8) 3673-3682.

McMLEAN RJ, BEAUCHEMIN D, CLAPHAM L and BEVERIDGE TJ (1990) Metal-binding characteristics of the gamma-glutamyl capsular polymer of Bacillus licheniformis ATCC 9945. Appl. Environ. Microbiol. 56 3671-3677.

OCHMAN H, LERAT E and DAUBIN V (2005) Examining bacterial species under the spectre of gene transfer and exchange. Proc. Nat. Acad. Sci. USA. 102 (1) 6595-6599.

ODENDAAL JP and REINECKE AJ (1999) The sublethal effects and accumulation of cadmium in the terrestrial isopod, Porcellio laevis Latr. (Crustacea, Isopoda). Arch. Environ. Contam. Toxicol. 36 64-69.

PIOTROWSKA-SEGET Z, CYCON M and KOZDROJ J (2005) Metaltolerant bacteria occurring in heavily polluted soil and mine spoil. Appl. Soil Ecol. 28 237-246.

RAWLINGS DE (1995) Restriction enzyme analysis of 16SrRNA genes for the rapid identification of Thiobacillus ferooxidans, Thiobacillus thiooxidans, Leptospirillum ferooxidans strains in leaching environments. In: Jerez CA, Vargas T, Toledo $\mathrm{H}$ and Wiertz JV (eds.) Biohydrometallurgical Processing, University of Chile Press, Santiago. 9-17.

ROANE TM and PEPPER IL (2000) Microorganisms and metal pollutants. In: Maier RM, Pepper IL and Gerba CP (eds.) Environmental Microbiology. Academic Press, San Diego. 403-423.

SAITOU N and NEI M (1987) The neighbour-joining method: a new method for reconstructing phylogenetic trees. Mol. Biol. Evol. 4 406-425.

SALEH MA, EWANE E, JONES J and WILSON BL (2000) Monitoring Wadi El Rayan lakes of the Egyptian desert for inorganic pollutants by ion-selective electrodes, ion chromatography, and inductively coupled plasma spectroscopy. Ecotoxicol. Environ. Saf. 45 310-316.

SELENSKA-POBELL S, PANAK P, MITEVA V, BOUDAKOV I, BERNHARD G and NITSCHE H (2006) Selective accumulation of heavy metals by three indigenous Bacillus strains, B. cereus, $B$. megaterium and $B$. sphaericus, from drain waters of a uranium waste pile. FEMS Microbiol. Ecol. 1 59-67.

TEITZEL GM and PARSEK MR (2003) Heavy metal resistance of biofilm and planktonic Pseudomonas aeruginosa. Appl. Environ. Microbiol. 69 2313-2320.

TRAJANOVSKA S, BRITZ ML and BHAVE M (1997) Detection of heavy metal ion resistance genes in Gram-positive and Gram-negative bacteria isolated from a lead-contaminated site. Biodegradation 8 113-124.

WRIGHT D and WELBOURNE P (2002) Environmental Toxicology. Factors affecting Toxicology. Cambridge Environmental Chemistry Series 11. Cambridge University Press, Cambridge.

YILMAZ EI (2004) Metal tolerance and biosorption capacity of Bacillus circulans strain EB1. Res Microbiol. 154 409-415. 